\title{
Coastal cooling and increased productivity in the main upwelling zone off Peru since the mid-twentieth century
}

\author{
Dimitri Gutiérrez, ${ }^{1,2}$ Ioanna Bouloubassi, ${ }^{3}$ Abdelfettah Sifeddine, ${ }^{3,4,5}$ Sara Purca, ${ }^{1}$ \\ Katerina Goubanova, ${ }^{6}$ Michelle Graco, ${ }^{1,2}$ David Field, ${ }^{7}$ Laurence Méjanelle, ${ }^{3}$ \\ Federico Velazco, ${ }^{1}$ Anne Lorre, ${ }^{3}$ Renato Salvatteci, ${ }^{1,3,4}$ Daniel Quispe, ${ }^{1}$ Gabriel Vargas, ${ }^{8}$ \\ Boris Dewitte, ${ }^{6}$ and Luc Ortlieb ${ }^{3,4}$
}

Received 10 December 2010; revised 13 February 2011; accepted 22 February 2011; published 14 April 2011.

[1] We reconstructed a high-resolution, alkenone-based sea surface temperature (SST) record spanning the last ca. 150 years, from a sediment core retrieved within the main upwelling zone off Peru. A conspicuous SST decline is evidenced since the 1950s despite interdecadal SST variability. Instrumental SST data and reanalysis of ECMWF ERA 40 winds suggest that the recent coastal cooling corresponds mainly to an intensification of alongshore winds and associated increase of upwelling in spring. Consistently, both proxy and instrumental data evidence increased productivity in phase with the SST cooling. Our data expand on previous reports on recent SST cooling in other Eastern Boundary upwelling systems and support scenarios that relate coastal upwelling intensification to global warming. Yet, further investigations are needed to assess the role of different mechanisms and forcings (enhanced local winds vs. spin-up of the South Pacific High Pressure cell). Citation: Gutiérrez, D., et al. (2011), Coastal cooling and increased productivity in the main upwelling zone off Peru since the mid-twentieth century, Geophys. Res. Lett., 38 , L07603, doi:10.1029/2010GL046324.

\section{Introduction}

[2] Eastern Boundary coastal upwelling systems (EBUSs) are hotspots of marine biological productivity in the global ocean. Particularly, the upwelling system off Peru is unequalled in terms of fish productivity, yielding biomasses one order of magnitude higher than other coastal upwelling systems [Chavez et al., 2008]. Ongoing and future modifications of EBUSs, potentially linked to global climate changes, have become an issue of increasing importance

\footnotetext{
${ }^{1}$ Dirección de Investigaciones Oceanográficas, Instituto del Mar del Perú (IMARPE), Callao, Peru.

${ }^{2}$ Programa Maestría en Ciencias del Mar, Universidad Peruana Cayetano Heredia, Lima, Peru.

${ }^{3}$ LOCEAN-IPSL (CNRS/IRD/UPMC/MNHN), Paris, France.

${ }^{4}$ LOCEAN-IPSL (CNRS/IRD/UPMC/MNHN), Centre IRD France-Nord, Bondy, France.

${ }^{5}$ Departamento de Geoquimica, Universidade Federal Fluminense, Niteroi, Brasil.

${ }^{6}$ LEGOS, UMR 5566, IRD, CNES, Toulouse, France.

${ }^{7}$ College of Natural and Computational Sciences, Hawaii Pacific University, Kaneohe, Hawaii, USA

${ }^{8}$ Departamento de Geología, Universidad de Chile, Santiago, Chile.

Copyright 2011 by the American Geophysical Union. 0094-8276/11/2010GL046324
}

since they may involve important ecosystem changes and associated socioeconomic impacts. It has been postulated an enhancement of alongshore wind stress and coastal upwelling as a response to global warming, due to increasing thermal gradient between the dry coast and the adjacent ocean [Bakun, 1990]. This response may be already operating in several upwelling regions, or may have occurred in the past under global/regional warming periods [Mendelssohn and Schwing, 2002; Leduc et al., 2010; Narayan et al., 2010].

[3] Off Peru, International Comprehensive OceanAtmosphere Dataset (ICOADS) records indicate increased alongshore wind stress since ca. 1940 [Jahncke et al., 2004; Bakun et al., 2010; Narayan et al., 2010]; yet, the reliability of ICOADS winds data set is being questioned [Bakun et al., 2010; Goubanova et al., 2010]. Reconstructions from highresolution marine sediment records are an alternative to document past and recent changes in the upwelling variability and the ecosystem response [McGregor et al., 2007; Vargas et al., 2007; Leduc et al., 2010]. We investigated SST and productivity trends of the Peruvian upwelling system, as inferred from laminated sediment records and instrumental time-series retrieved off Pisco $\left(\sim 14^{\circ} \mathrm{S}\right)$ within the main upwelling zone. We report here reconstructed coastal SST records based on the alkenone- $U_{37}^{\mathrm{k}^{\prime}}$ index spanning the last ca. 150 years and we compile them with available instrumental and satellite-derived information of coastal winds and SST. Proxy records of alkenones and total organic carbon, and time series of surface Chlorophyll-a (Chl-a) contents are used to infer productivity changes.

\section{Material and Methods}

[4] Box core B0406 $\left(14^{\circ} 07.9^{\prime} \mathrm{S}, 7^{\circ} 30.1^{\prime} \mathrm{S}, 299 \mathrm{~m}\right.$ water depth) was collected from a laminated mud-lens, on the upper continental margin off Pisco, central-southern Peru in 2004 (Figure 1). The age model was based on downcore profiles of ${ }^{241} \mathrm{Am}$, excess ${ }^{210} \mathrm{~Pb}$ and radiocarbon dating [Gutiérrez et al., 2009]. Sedimentation rates varied from $1.9 \mathrm{~mm} \mathrm{y}^{-1}$ (1860-1952) to $2.3 \mathrm{~mm} \mathrm{y}^{-1}$ (after 1952) on average. The time resolution of sample slices is 1-3 years.

[5] For alkenone analyses, lipids were extracted and separated using the procedure described by Bouloubassi et al. [2009]. The alkenone fractions were analyzed with a gas chromatograph (Agilent 6890) equipped with a flame ionization detector and fitted with a fused silica capillary column (CPSil5CB, $50 \mathrm{~m} \times 0.32 \mathrm{~mm} \times 0.25 \mu \mathrm{m})$. Temperatures were estimated from the $U_{37}^{k^{\prime}}$ index $\left(\left(C_{37: 2}\right) /\right.$ $\left.\left(\mathrm{C}_{37: 2}+\mathrm{C}_{37: 3}\right)\right)$ using the calibration of Prahl and Wakeham 
a

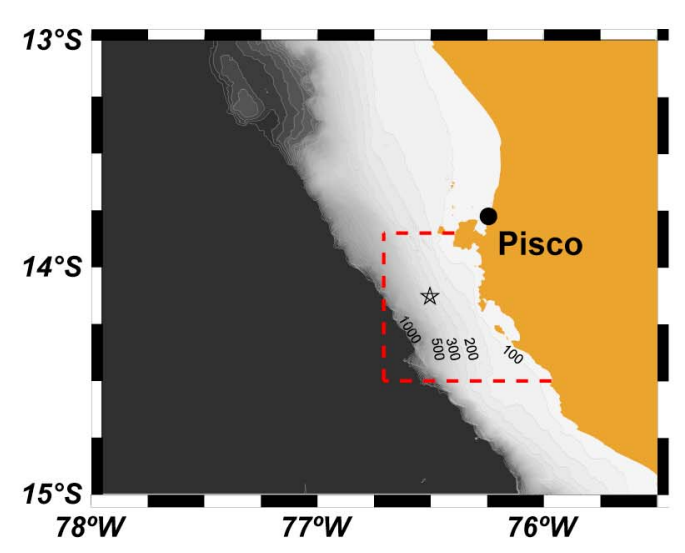

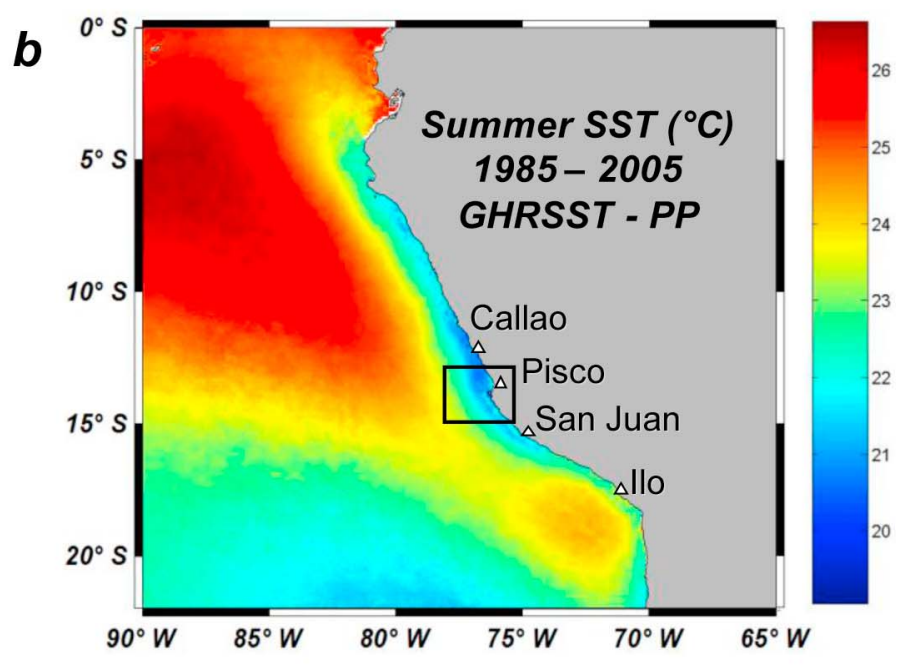

C

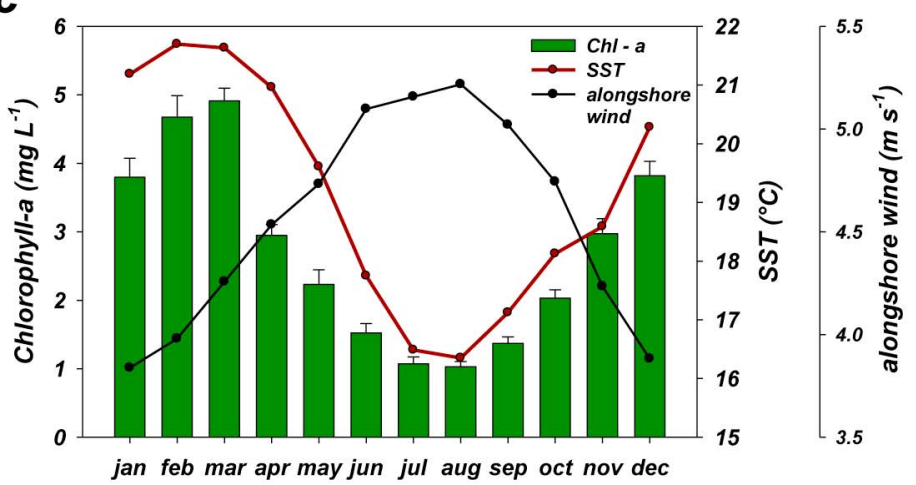

Figure 1. (a) Location of boxcore B0406 (star); (b) average summer SST distribution off Peru (GHRSST-PP: 1985-2005). The black dot corresponds to the boxcore. White triangles indicate IMARPE piers; (c) climatology of Chl-a based on SeaWiFS color data (1997-2006) and of the alongshore wind velocities (ECMWF-ERA40) inside the coastal core area depicted with a dashed red box in Figure 1a. The red line joins the monthly SST-means, based on a least squares fit between Pisco pier SST and GHRSST.

[1987]. Total organic carbon was determined from total carbon measurements with a Thermo Electron CNS analyzer, corrected for carbonate content.

[6] A climatology of Chl-a was calculated based on daily SeaWiFS data $(10 \times 10 \mathrm{~km})$. Annual means of in situ Chl-a (1965-2004) were estimated from the World Ocean Database (http://www.nodc.noaa.gov/OC5/WOD/pr_wod.html) and from surveys performed by the Instituto del Mar del Peru (IMARPE). Quarterly time-series of surface winds (1958-2001) were obtained from the ERA 40 reanalysis [Uppala et al., 2005] at ca. $100 \times 100 \mathrm{~km}$ resolution. The ERA 40 reanalysis is preferred to the ICOADS winds or the NCEP/NCAR reanalysis because it better agrees with ERS satellite data [Goubanova et al., 2010, Table 2]. SST data ( 1860-2005) were extracted from ICOADS within $55 \mathrm{~km}$ off Pisco $\left(13-16^{\circ} \mathrm{S}\right)$. The Pathfinder High Resolution SST dataset was also used (1985-2005) at $4 \mathrm{~km}$ resolution (GHRSST-PP) [Vasquez-Cuervo et al., 2010]. Objective interpolation was performed to fill in the missing values associated with cloud cover. We also used this product to estimate quarterly time-series and seasonal climatologically maps. Monthly coastal SST time-series were obtained from four piers along the Central-Southern Peruvian coast: Pisco $\left(13^{\circ} 45^{\prime}\right)$, Callao $\left(12^{\circ} \mathrm{S}\right)$, San Juan $\left(15.5^{\circ} \mathrm{S}\right)$ and Ilo $\left(17^{\circ} \mathrm{S}\right)$.

\section{Results and Discussion}

\subsection{Environmental Setting}

[7] The Pisco area is subjected to the most intense alongshore winds in the Peruvian coast [Goubanova et al., 2010]. Upwelling here is active year-round but stronger during winter/spring, as observed from the climatological SST and alongshore winds. In turn, primary productivity is higher during spring/summer, when surface waters are more stratified, while austral winter is less productive (Figure 1). A pronounced cross-shore SST gradient is developed from spring to summer (auxiliary material), giving rise to a conspicuous 'cold tongue' that likely reflects a persistent upwelling cell during the peak productivity period, surrounded by more stratified waters. ${ }^{1}$

${ }^{1}$ Auxiliary materials are available in the HTML. doi:10.1029/ 2010GL046324. 
a

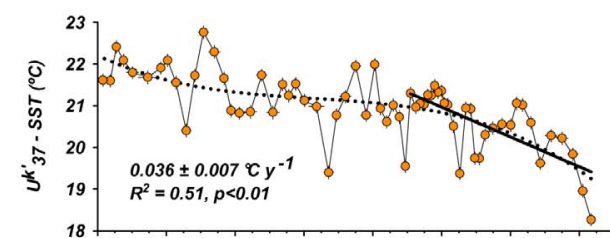

b

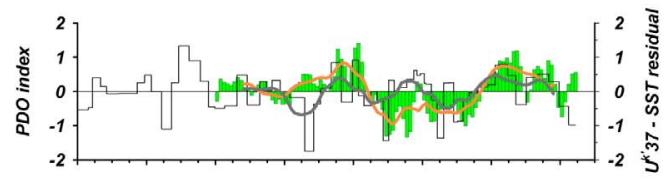

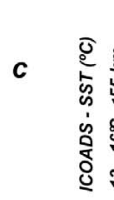

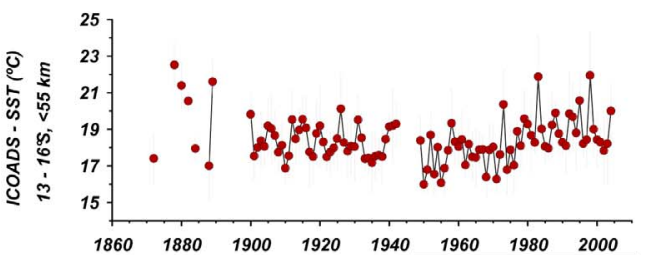

d

e

$f$

g

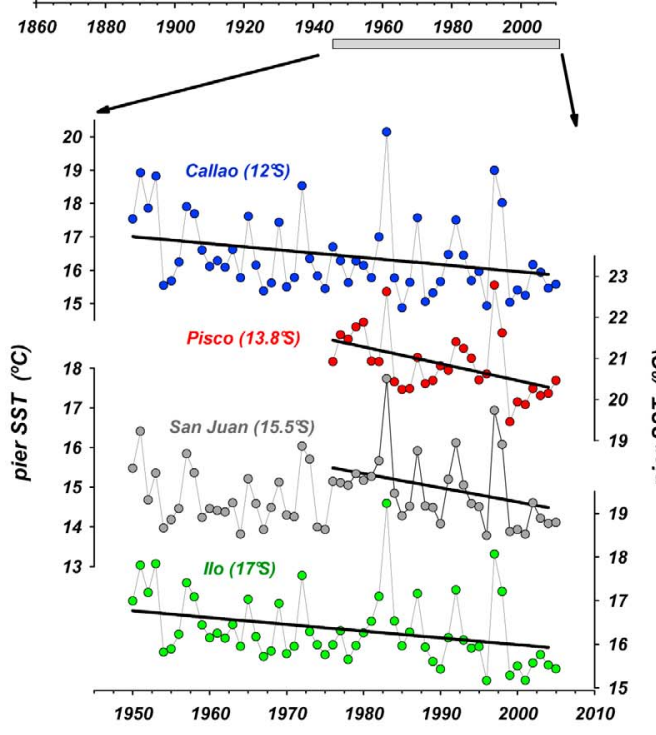

Figure 2. (a) $\mathrm{U}_{37^{\mathrm{k}^{\prime}}}-\mathrm{SST}$ s from boxcore B0406. The dotted line is the cubic order polynomial fit to the entire series $\left(\mathrm{R}^{2}=0.52\right)$; the solid line depicts the negative trend since $1950 \mathrm{AD}\left(-0.04 \pm 0.01^{\circ} \mathrm{C} \mathrm{y}^{-1}, \mathrm{n}=30, \mathrm{p}<0.01, \mathrm{R}^{2}=\right.$ 0.51 ); (b) $\mathrm{U}_{37}^{\mathrm{k}^{\prime}}-\mathrm{SST}$ polynomial model residuals (black line) and annual PDO index (3-term running means in green histogram) [Mantua et al., 1997]. The thick grey and orange lines show the corresponding series smoothed with $10 \mathrm{yr}$ running average filter (see text); (c) summer/spring ICOADS SSTs (means and range); (d-g) SSTs (annual means) measured in the piers shown in Figure 1b. The solid lines depict linear regression fits for Callao $\left(>1950\right.$ : $-0.02 \pm 0.01^{\circ} \mathrm{C} \mathrm{y}^{-1}$, $\mathrm{p}<0.05$ ), Pisco ( $>1976$, no data before: $-0.04 \pm 0.02^{\circ} \mathrm{C}^{-1}$, $\mathrm{p}<0.05)$, San Juan $\left(>1976:-0.04 \pm 0.02^{\circ} \mathrm{C}^{-1}, \mathrm{p}<0.05\right)$, and Ilo $\left(>1950:-0.02 \pm 0.01^{\circ} \mathrm{C}^{-1}, \mathrm{p}<0.05\right)$.

\subsection{Disentangling the Proxy Temperature Signal}

[8] Core-top $\mathrm{U}_{37^{\prime}}^{\mathrm{k}^{\prime}} \mathrm{SST}\left[18.3 \pm 0.3^{\circ} \mathrm{C}\right]$ falls within the range of the present day typical summer thermocline temperatures. In contrast, during winter the water column is totally mixed and colder than the core-top $\mathrm{U}_{37^{k^{\prime}}}-\mathrm{SST}$ (auxiliary material). Correlations between the $\mathrm{U}_{37}^{\mathrm{k}}$-SST record and SST time-series from the Pisco pier shows that the former better reflects the composite spring/summer conditions. In turn, the Pisco pier SSTs are better correlated with satellite-derived GHRSSTs from the 'cold-tongue', which indicates the upwelling control on pier's records. Also, compared with GHRSSTs, the $\mathrm{U}_{37}^{\mathrm{k}^{\prime}}$-SST record exhibits a significant correlation $(p<0.1)$ with the composite spring/ summer SSTs confined to the 'cold-tongue' (see auxiliary material for the statistical correlations). Consequently, we interpret the $\mathrm{U}_{37}^{\mathrm{k}^{\prime}}-\mathrm{SST}$ as indicative of the shallower thermocline driven by coastal upwelling during spring/summer, i.e., when primary productivity is highest and the open oceancoast SST gradient is stronger.

\subsection{From Decadal Variability to Recent Trends in SST}

[9] A cubic polynomial fit to the $\mathrm{U}_{37}^{\mathrm{k}^{\prime}}-\mathrm{SST}$ record depicts a non-linear cooling, which can be roughly summarized in three multidecadal periods: i) Before 1900, whereby the highest $\mathrm{U}_{37}^{\mathrm{k}^{\prime}}$-SSTs are found; ii) from $\sim 1901$ to $\sim 1945$, when average and maximal $\mathrm{U}_{37^{\mathrm{k}^{\prime}}}$-SSTs are lower; and iii) after 1950 , featured by a rapid cooling $\left(-0.36 \pm 0.07^{\circ} \mathrm{C} \mathrm{decade}^{-1}\right)$ (Figure $2 \mathrm{a}$ and auxiliary material).

[10] We analyzed the relationship between the model residuals and the El Niño Southern Oscillation (ENSO) chronology [Ortlieb, 2000; Gergis and Fowler, 2009] as well as with the Pacific Decadal Oscillation (PDO) [Mantua et al., 1997] at decadal scales. The positive residuals from the model correspond to several strong El Niño events, but the record fails to identify La Niña events and weak/moderate El Niño events (auxiliary material). The imprint of ENSO in the sedimentary record is likely attenuated by the resolution of the sectioning interval [McCaffrey et al., 1990], and probably by differences in coccolithophorids productivity under warm or cool ENSO events. In contrast, the signature of PDO was identified in our record (Figure 2b). Firstly, the PDO index was sampled on the time scale corresponding to the proxy SST series: the mean PDO values for each sample interval were calculated based on the monthly PDO index [Mantua et al., 1997]. Then both series were interpolated on the annual time scale using cubic spline interpolation, and the 10-year running mean was applied. The smoothed series are positively correlated over the entire period (Pearson's $r=0.45, p<0.001$ ), and particularly since $1930(\mathrm{r}=0.69, \mathrm{p}<0.001)$, indicating a large-scale modulation of the coastal SSTs, superimposed on the non-linear cooling trend. PDO shifts in early 1940's and in mid 1970's are well recorded. In contrast, before 1930 the residuals are out of phase with the PDO index, which exhibits a weaker variability $(\mathrm{r}=-0.55, \mathrm{p}<0.001)$.

[11] We compared the $\mathrm{U}_{37^{\mathrm{k}^{\prime}}-\mathrm{SST}} \mathrm{Secord}$ with the instrumental ICOADS-SST off Pisco $\left(13-16^{\circ} \mathrm{S}\right)$ during the austral spring/summer (October to March) (Figure 2c). Before 1900 (even though the ICOADS-SST data are scarce), higher maximal temperatures were recorded relative to the period 1900-1945, in agreement with the $\mathrm{U}_{37}^{\mathrm{k}^{\prime}}$-SSTs. After 1950, both records show a temperature decrease towards the late 1960s, but the ICOADS time-series exhibits a steep warming from 1970 to $1980\left(+2.5^{\circ} \mathrm{C}\right)$, shifting the SST baseline upwards. Instead, the $\mathrm{U}_{37^{\prime}}^{\mathrm{k}^{\prime}}-\mathrm{SST}$ record depicts a slight warming in the 1970 's $\left(+0.8^{\circ} \mathrm{C}\right)$ superimposed on the rapid negative trend, and a very pronounced cooling occurring from 1980 to $2004\left(-2.5^{\circ} \mathrm{C}\right)$. However, the ICOADSSSTs database may under-represent cold, strong wind-driven 

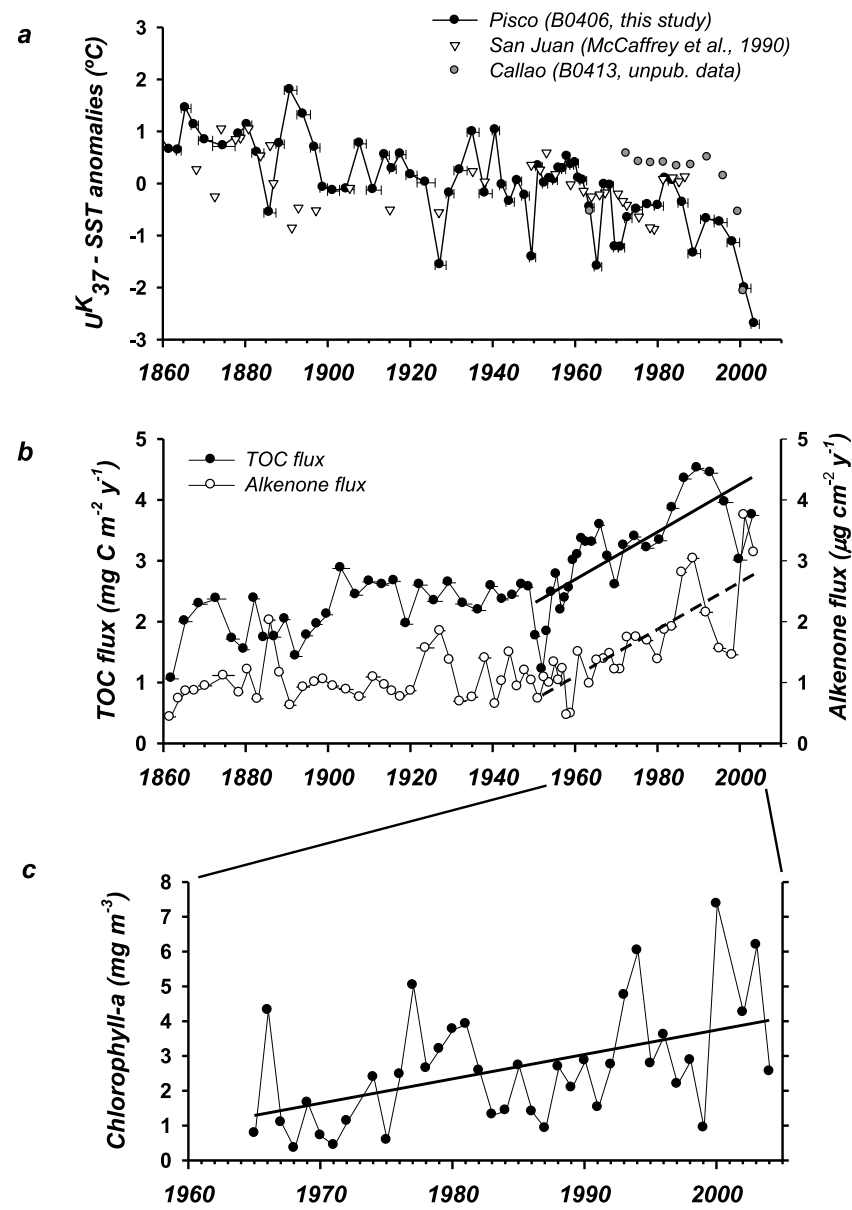

Figure 3. (a) $\mathrm{U}_{37^{\prime}}^{\mathrm{k}^{\prime}}-\mathrm{SST}$ anomalies over the long-term means from Pisco (this study), San Juan (15.5 $\mathrm{S}$ [McCaffrey et al., $1990])$, and Callao $\left(12^{\circ} \mathrm{S}\right.$, boxcore B0413 (I. Bouloubassi, unpublished data, 2010); (b) TOC and alkenone fluxes; the positive trends after 1950 are estimated by linear fits in $0.04 \pm$ $0.01 \mathrm{mg} \mathrm{cm}^{-2} \mathrm{y}^{-1}\left(\mathrm{n}=26, \mathrm{p}<0.001, \mathrm{R}^{2}=0.58\right)$ for the TOC flux and $0.04 \pm 0.01 \mathrm{mg} \mathrm{cm}^{-2} \mathrm{y}^{-1}\left(\mathrm{n}=27, \mathrm{p}<0.001, \mathrm{R}^{2}=\right.$ 0.62 ) for the alkenone flux; (c) annual means of surface Chlorophyll-a contents $\left(\mathrm{mg} \mathrm{m}^{-3}\right)$ within $100 \mathrm{Km}_{\text {off the coast }}$ $\left(13.5-14.5^{\circ} \mathrm{S}\right)$; the positive trend is estimated by a linear fit in $0.07 \pm 0.02 \mathrm{mg} \mathrm{m}^{-3} \mathrm{y}^{-1}\left(\mathrm{n}=38, \mathrm{p}<0.01, \mathrm{R}^{2}=0.21\right)$.

episodes in nearshore areas since they are usually followed by navigation bans. The divergence between the two data sets since $\sim 1970$ may suggest an intensification of the cross-shore temperature gradient and/or of the thermocline gradient.

[12] In line with the $\mathrm{U}_{37^{\prime}}^{\mathrm{k}^{\prime}}-\mathrm{SST}$ record, inshore (pier) annual SST time-series from Central and Southern Peru document a significant cooling (Figures $2 \mathrm{~d}-2 \mathrm{~g}$ ), either since the $1950 \mathrm{~s}$ or after the mid $1970 \mathrm{~s}$, varying from $-0.02^{\circ} \mathrm{C} \mathrm{y}^{-1}$ to $-0.04^{\circ} \mathrm{C}^{-1}$. Trends are mainly explained by spring months and in a lesser extent by summer months (see auxiliary material). Both inshore SST data and $\mathrm{U}_{37}^{\mathrm{k}^{\prime}}-\mathrm{SST}$ are thus recording a similar magnitude of SST decline. An earlier, lower-resolution study of a sediment core off Peru (San Juan, $15.5^{\circ} \mathrm{S}$ ) that presents a similar multidecadal variation in $\mathrm{U}_{37^{\prime}}^{\mathrm{k}^{\prime}}-\mathrm{SST}$, also shows a marked SST drop from
1950 to ca.1986 (core-top), except for the 1983 El Niño event [McCaffrey et al., 1990]. $\mathrm{U}_{37}^{\mathrm{k}^{\prime}}$-SSTs from a core off Callao $\left(12^{\circ} \mathrm{S}\right)$ also exhibit a SST decline in the last decades (Figure 3a). Thus, these sedimentary records add further evidence for a regional cooling trend in recent decades along the Central/Southern Peruvian coast.

\subsection{Trends in Primary Productivity Proxies}

[13] In phase with the SST cooling, a positive trend of alkenone and total organic carbon (TOC) fluxes is recorded (Figure 3b), pointing to a concomitant enhancement of primary productivity. Consistent with this, instrumental data off Pisco (since 1965) clearly exhibit a rise of surface Chl-a (Figure $3 b$ ). An increased trend of primary productivity has been detected by remote sensing for the past decade [Demarcq, 2009]. Our proxy results extend back to the 1960s the onset of this positive trend.

[14] Seasonality of surface Chl-a and alongshore winds suggest that primary productivity falls in winter because surface insolation is lower and wind mixing depth exceeds threshold limits for algal growth [Mann and Lazier, 2006]. Thus, enhanced alongshore winds intensities during spring and/or summer might explain the observed productivity trends provided they do not exceed critical levels; a deeper threshold limit in wind mixing should be associated to the seasonal rise of surface insolation. Also, warming offshore, as suggested by ICOADS-SST or satellite data since the 1980's (auxiliary material), might contribute to a rapid onshore intrusion of stratified waters when coastal upwelling is relaxed, favoring the development of plankton blooms.

\subsection{Local to Global Forcing}

[15] Previous investigations have indicated a regional positive trend of ICOADS' alongshore winds ca. $200 \mathrm{~km}$ off the Peruvian coast [Bakun et al., 2010; Narayan et al., 2010]. We obtained similar trends for ICOADS' winds within $110 \mathrm{~km}$ off the central-southern coast (not shown). Given the debate on the reliability of ICOADS winds [Bakun et al., 2010; Goubanova et al., 2010], independent wind data sources are being used for climatic/dynamic studies near the coast. Narayan et al. [2010] found a positive trend using annual averages of ERA 40 winds at $2.5 \times$ $2.5^{\circ}$ of resolution for the Central/Southern Peruvian coast. Using ERA 40 winds at higher spatial resolution $\left(1.25^{\circ} \times\right.$ $1.25^{\circ}$ ), our analysis shows that the positive trend in alongshore wind stress occurs during spring (Table 1 and auxiliary material), which is consistent with the seasonal pattern of the recent coastal cooling and productivity mentioned above. From a regional point of view, the coastal cooling trend affecting Central/Southern Peru coincides with the variation of coastal SST in Northern Chile measured since 1979 [Falvey and Garreaud, 2009], both in sign and magnitude (average range $\sim-0.2$ to $-0.4^{\circ} \mathrm{C}$ decade $^{-1}$ ). This strongly suggests a common forcing process; e.g., an intensification of the South Pacific High Pressure Cell [Falvey and Garreaud, 2009], or an enhancement of local alongshore winds in response to increasing land-sea pressure gradient [Bakun, 1990]. It was postulated that both processes are triggered by anthropogenic global warming [Falvey and Garreaud, 2009; Bakun, 1990].

[16] Recently, SST records from marine sediments revealed a sharp SST cooling during the latter part of the 
Table 1. Regression Models of ERA40 Alongshore Wind Velocities Versus Time at the Four Annual Seasons

\begin{tabular}{lccc}
\hline $\begin{array}{c}\text { Dependent } \\
\text { Variable }\end{array}$ & $\mathrm{R}^{2}$ & $\mathrm{p}$-Value & $\begin{array}{c}\text { Slope } \pm \text { Std. Error } \\
\left(\mathrm{m} \mathrm{s}^{-1} \text { decade }^{-1}\right)\end{array}$ \\
\hline All seasons & 0.02 & 0.10 & $0.10 \pm 0.06$ \\
Summer & - & 0.92 & - \\
Fall & - & 0.70 & - \\
Winter & 0.03 & 0.26 & - \\
Spring & 0.22 & 0.001 & $0.28 \pm 0.08$ \\
\hline
\end{tabular}

20th century in the coastal upwelling area off NW Africa (ca $30.5^{\circ} \mathrm{N}$ ) [McGregor et al., 2007], and in the southern Benguela upwelling system (ca $\left.29^{\circ} \mathrm{S}\right)$ [Leduc et al., 2010], with rates of $\sim-0.2^{\circ} \mathrm{C}$ decade $^{-1}$ and $\sim-0.7^{\circ} \mathrm{C}$ decade $^{-1}$, respectively, within the same range of the Peruvian cooling trends. Some of these records are supported by instrumental observations of winds, coastal SSTs [Bakun et al., 2010; Narayan et al., 2010], and water vapor, the main green house gas [Bakun et al., 2010]. Our records do not provide direct evidence of alongshore wind intensification during summer, as it would be expected from Bakun's mechanism. Nevertheless, some of the pier's SST data indicate a coastal cooling trend in summer temperatures over the study period (see auxiliary material), suggesting an increase of nearshore upwelling winds perhaps not captured by ERA 40 resolution.

\section{Concluding Remarks}

[17] Alkenone SST reconstructions from a high-resolution coastal sediment core off Peru show a significant steady cooling $\left(\sim 0.3-0.4^{\circ} \mathrm{C} \mathrm{decade}^{-1}\right)$ for the latter part of the 20 th century. Instrumental SST data confirm this coastal cooling trend, and ERA 40 reanalysis indicates its link with intensified alongshore winds driving upwelling in spring. A concurrent increase in marine productivity is assigned to the interplay between stronger upwelling and rapid thermal stratification when upwelling is relaxed, favoured by offshore warming, as suggested by ICOADS and satellite SST time series. The consistency of our records with those from other EBUSs supports scenarios that relate coastal upwelling intensification to global warming. In the upwelling off Peru, the role of the postulated mechanisms, e.g., enhanced local winds due to land-sea thermal gradients or spin-up of the South Pacific High Pressure cell, is not yet fully constrained; for this, further meteorological data, large-scale fields of atmospheric pressure and surface winds and/or regional high-resolution modeling are critically needed. Finally, intensification of coastal upwelling may have important ongoing/future impacts on the biogeochemical cycling (e.g., air-sea gas fluxes, export production, redox dynamics) and ecosystem responses, which need to be assessed.

[18] Acknowledgments. This study was supported by IMARPE (Peru), the research unit LOCEAN - IPSL (UMR 7192 CNRS/ IRD/UPMC/MNHN) in France and the projects JEAI MIXPALEO, PALEOPECES, PALEOTRACES, DISCOH, PCCC and the 'Cátedra CONCYTEC en Ciencias del Mar'. We thank Jorge Vasquez (JPL) for providing the $4 \mathrm{~km}$ resolution GHRSST-PP SST data and David Correa for performing the objective interpolation of these data. Finally, we thank Francisco Chavez and Monique Messié, with whom we sustained sound discussions that helped us for the preparation of this paper.
[19] The Editor thanks two anonymous reviewers for their assistance in evaluating this paper.

\section{References}

Bakun, A. (1990), Global climate change and intensification of coastal ocean upwelling, Science, 247, 198-201, doi:10.1126/science.247.4939.198.

Bakun, A., D. Field, A. Redondo-Rodriguez, and S. J. Weeks (2010), Greenhouse gas, upwelling-favorable winds, and the future of coastal ocean upwelling ecosystems, Global Change Biol., 16, 1213-1228, doi:10.1111/j.1365-2486.2009.02094.x.

Bouloubassi, I., E. Nabais, R. D. Pancost, A. Lorre, and M.-H. Taphanel (2009), First biomarker evidence for methane oxidation at cold seeps in the south east Atlantic (REGAB pockmark), Deep Sea Res., Part II, 56, 2239-2247, doi:10.1016/j.dsr2.2009.04.006.

Chavez, F. P., A. Bertrand, R. Guevara-Carrasco, P. Soler, and J. Csirke (2008), The northern Humboldt Current system: Brief history, present status and a view towards the future, Prog. Oceanogr., 79, 95-105, doi:10.1016/j.pocean.2008.10.012.

Demarcq, H. (2009), Trends in primary production, sea surface temperature and wind in upwelling systems (1998-2007), Prog. Oceanogr., 83, 376-385, doi:10.1016/j.pocean.2009.07.022.

Falvey, M., and R. D. Garreaud (2009), Regional cooling in a warming world: Recent temperature trends in the southeast Pacific and along the west coast of southtropical South America (1979-2006), J. Geophys. Res., 114, D04102, doi:10.1029/2008JD010519.

Gergis, J., and A. Fowler (2009), A history of ENSO events since A.D. 1525: Implications for future climate change, Clim. Change, 92, 343-387, doi:10.1007/s10584-008-9476-z.

Goubanova, K., V. Echevin, B. Dewitte, F. Codron, K. Takahashi, P. Terray, and M. Vrac (2010), Statistical downscaling of sea-surface wind over the Peru-Chile upwelling region: Diagnosing the impact of climate change from the IPSL-CM4 model, Clim. Dyn., doi:10.1007/s00382-010-0824-0.

Gutiérrez, D., et al. (2009), Rapid reorganization in ocean biogeochemistry off Peru towards the end of the Little Ice Age, Biogeosciences, 6, 835-848, doi:10.5194/bg-6-835-2009.

Jahncke, J., D. M. Checkley Jr., and G. L. Hunt Jr. (2004), Trends in carbon flux to seabirds in the Peruvian upwelling system: Effects of wind and fisheries on population regulation, Fish. Oceanogr., 13(3), 208-223, doi:10.1111/j.1365-2419.2004.00283.x.

Leduc, G., C. Herbert, T. Blanz, P. Martínez, and R. Schneider (2010), Contrasting evolution of sea surface temperature in the Benguela upwelling system under natural and anthropogenic climate forcings, Geophys. Res. Lett., 37, L20705, doi:10.1029/2010GL044353.

Mann, K. H., and J. R. N. Lazier (2006), Dynamics of Marine Ecosystems, 3rd ed., 512 pp., Blackwell, Malden, Mass.

Mantua, N. J., S. R. Hare, Y. Zhang, J. M. Wallace, and R. C. Francis (1997), A Pacific interdecadal climate oscillation with impacts on salmon production, Bull. Am. Meteorol. Soc., 78, 1069-1079, doi:10.1175/15200477(1997)078<1069:APICOW>2.0.CO;2.

McCaffrey, M., J. Farrington, and D. Repeta (1990), The organic geochemistry of Peru margin surface sediments: I. A comparison of the $\mathrm{C}_{37}$ alkenone and historical El Niño records, Geochim. Cosmochim. Acta, 54, 1671-1682, doi:10.1016/0016-7037(90)90399-6.

McGregor, H. V., M. Dima, H. W. Fischer, and S. Mulitza (2007), Rapid 20 th century increase in coastal upwelling off northwest Africa, Science, 315, 637-639, doi:10.1126/science.1134839.

Mendelssohn, R., and F. B. Schwing (2002), Common and uncommon trends in SST and wind stress in the California and Peru-Chile Current systems, Prog. Oceanogr., 53, 141-162, doi:10.1016/S0079-6611(02) 00028-9.

Narayan, N., A. Paul, S. Mulitza, and M. Schulz (2010), Trends in coastal upwelling intensity during the late 20th century, Ocean Sci., 6, 815-823, doi:10.5194/os-6-815-2010.

Ortlieb, L. (2000), The documentary historical record of El Niño events in Peru: An update of the Quinn record (sixteenth through nineteenth centuries), in El Niño and the Southern Oscillation: Variability, Global and Regional Impacts, edited by H. Diaz and V. Markgraf, pp. 207-295, Cambridge Univ. Press, Cambridge, U. K.

Prahl, F. G., and S. G. Wakeham (1987), Calibration of unsaturation patterns in long-chain ketone compositions for paleotemperature assessment, Nature, 330, 367-369, doi:10.1038/330367a0.

Uppala, S. M., et al. (2005), The ERA-40 re-analysis, Q. J. R. Meteorol. Soc., 131, 2961-3012, doi:10.1256/qj.04.176.

Vargas, G., S. Pantoja, J. A. Rutllant, C. B. Lange, and L. Ortlieb (2007), Enhancement of coastal upwelling and interdecadal ENSO-like variability in the Peru-Chile Current since late 19th century, Geophys. Res. Lett., 34 L13607, doi:10.1029/2006GL028812. 
Vasquez-Cuervo, J., E. M. Armstrong, K. S. Casey, R. Evans, and K. Kilpatrick (2010), Comparison between the Pathfinder versions 5.0 and 4.1 sea surface temperature datasets: A case study for high resolution, J. Clim., 23, 1047-1059, doi:10.1175/2009JCLI2839.1.

I. Bouloubassi, A. Lorre, L. Méjanelle, L. Ortlieb, R. Salvatteci, and A. Sifeddine, LOCEAN-IPSL (CNRS, IRD, UPMC, MNHN), 4 place Jussieu, F-75252 Paris CEDEX 05, France.
B. Dewitte and K. Goubanova, LEGOS, UMR 5566, IRD, CNES, 18, Av. Edouard Belin, F-31401 Toulouse CEDEX 9, France.

D. Field, College of Natural and Computational Sciences, Hawaii Pacific University, 45-045 Kamehameha Hwy., Kaneohe, HI 96744-5297, USA.

M. Graco, D. Gutiérrez, S. Purca, D. Quispe, and F. Velazco, Dirección de Investigaciones Oceanográficas, Instituto del Mar del Perú (IMARPE), Esquina Gamarra y General Valle S/N, Callao, Peru. (dgutierrez@imarpe.pe) G. Vargas, Departamento de Geología, Universidad de Chile, Casilla 13518-Correo 21, Santiago, Chile. 